\title{
Collagen Metabolism in the Fibroblasts Derived from the Skin of a 16-year-old Patient with Marfan Syndrome: A Decreased Rate of Intracellular Degradation of Collagen
}

\author{
Shingo Tajima \\ Department of Dermatology, School of Medicine, Keio University, Tokyo, Japan \\ (Received for publication on April 28, 1995)
}

\begin{abstract}
The rate of collagen synthesis in the cell layer fraction of the skin fibroblasts derived from a patient with Marfan syndrome was greater than that in the normal fibroblasts. Neither the relative content of type III collagen nor the level of prolyl and lysyl hydroxylations in type I collagen changed. Intracellular degradation rate of collagen in Marfan syndrome fibroblasts was decreased to one fifth of that in the normal fibroblasts. These results suggest that abnormal collagen metabolism may be related to the pathogenesis of clinical manifestations of Marfan syndrome. (Keio J Med 44 (3): 88-92, 1995)
\end{abstract}

Key words: collagen, collagen degradation, Marfan syndrome

\section{Introduction}

Marfan syndrome is a heritable systemic disease which is characterized by arachnodactly, ectopia lentis, or aortic dissection. ${ }^{1}$ Over the years, major classes of connective tissue components including collagen, elastin and proteoglycan have been suggested to be defective in this disease.

From the earlier reports of the increased urinary excretion of hydroxyproline,,$^{2,3}$ the increased solubility of dermal collagen ${ }^{3,4}$ and the decreased borohydrideresistant collagen cross-links, ${ }^{5}$ fibrillar collagen has been believed as the cause of Marfan syndrome.

It has been reported that increased synthesis of hyaluronic acid $^{6,7}$ or deficient transcription of decorin, a chondroitin-dermatan sulfate proteoglycan ${ }^{8}$ was found in Marfan syndrome fibroblasts.

Indirect evidence for a defect in elastin in Marfan syndrome came from studies documenting decreased excretion of desmosins, a cross-link structure of insoluble elastin, in the urine of patients ${ }^{y}$ and increased solubility of elastin from the aorta of Marfan patients. ${ }^{10}$

Recently it has been demonstrated that Marfan syndrome is caused by mutations in the fibrillin gene, encoding a major protein constituting microfibrillar glycoproteins. ${ }^{11-1+}$ However the previous reports de- scribing the abnormalities in collagen, elastin and proteoglycans in Marfan syndrome suggest that the defects in fibrillin influence the metabolisms of other extracellular matrix components, since fibrillin is thought to interact with other matrix proteins. Marfan syndrome exhibits heterogeneous clinical phenotypes, which can be explained by a defective fibrillin, but its actual pathogenic mechanism remains still speculative.

Intracellular degradation of protein is a fundamental process with important implications for the protein regulation and cell biology. Intracellular degradative rates have been found to correlate with certain physical and chemical properties of the protein, such as charge size proteolytic susceptibility and hydrophobic character. ${ }^{15}$

In this study, I found an increased synthesis of collagen in the cell layer of Marfan syndrome fibroblasts which is due to decreased intracellular degradation rate of collagen.

\section{Case Report}

A 16-year-old Japanese male referred to dermatology clinic with an extensive linear atrophic skin changes. His height was taller $(181 \mathrm{~cm})$ than the mean for his age. Funnel chest (pectus excavatum) was observed but 
vertebral column deformity was not seen. Ophthalmic examination revealed ectopia lentis. Electrocardiogram and echocardiogram showed mitral valve prolapse due to floppy mitral valve. Marked striae distensae on his shoulders, thigh and abdomen were noted. Breast X-p and barium enema were normal. Hypermobility of joints and hyperextensibility of the skin suggesting EhlersDanlos syndrome were not observed.

\section{Materials and Methods}

\section{Materials}

$\left[2,3-{ }^{3} \mathrm{H}\right]$ Proline $\quad(4.0 \mathrm{TBq} / \mathrm{mmol}), \quad\left[\mathrm{U}-{ }^{14} \mathrm{C}\right] \quad$ lysine $(12 \mathrm{GBq} / \mathrm{mmol})$ and $\left[{ }^{32} \mathrm{P}\right] \mathrm{dCPT}(110 \mathrm{TBq} / \mathrm{mmol})$ were purchased from Amersham. Multiprime DNA labeling kit was from Amersham, and Dulbecco's modified Eagle's medium (DMEM) and fetal bovine serum (FBS) were from Gibco. Chromatographically purified bacterial collagenase was from Advance Biofactures Company, pepsin was from Cooper Biomedical, and nitrocellulose filters were from Scheleicher \& Schuell.

\section{Fibroblast culture}

Fibroblasts were explanted from skin biopsy samples of the patient and two age-, sex- and site-matched controls. Cells grown in 35-mm Petri dishes in DMEM containing $10 \%$ FBS were routinely subcultured every 6 days. Cells in passages $8-10$ were used.

\section{Metabolic labeling and collagen synthesis}

Confluent cultures were labeled for $24 \mathrm{~h}$ with [2,3${ }^{3} \mathrm{H}$ ]proline $(20 \mu \mathrm{Ci} / \mathrm{ml})$ in the presence of ascorbic acid $(50 \mu \mathrm{g} / \mathrm{ml})$. The medium was then collected and mixed with a protease inhibitor cocktail to yield $1 \mathrm{mM}$ each of

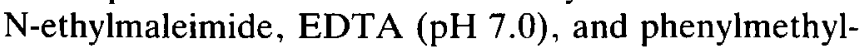
sulfonyl fluoride. The cells were harvested with $0.05 \%$ trypsin, and their number was determined with a Coulter counter. After centrifugation, cells were recombined with the medium and stored at $-20^{\circ} \mathrm{C}$ until ready for analysis. The amount of radioactivity incorporated into collagen and total proteins was determined using purified bacterial collagenase ${ }^{16}$ as previously described. ${ }^{17}$ Syntheses of collagen was expressed as collagenase-sensitive $\mathrm{cpm} / \mathrm{cell}$.

\section{Synthesis type I and III collagens}

Confluent cultures were labeled as described above. The culture medium was collected and the cell layer was scraped and homogenized with $0.5 \mathrm{M}$ acetic acid, and the homogenate was centrifuged at $13000 \times \mathrm{g}$ for $30 \mathrm{~min}$ at $4^{\circ} \mathrm{C}$. The resulting supernatant was combined with the culture medium, dialyzed against $0.1 \%$ acetic acid at $4^{\circ} \mathrm{C}$, and lyophilized. The material was digested with pepsin $(50 \mu \mathrm{g} / \mathrm{ml})$ for $18 \mathrm{~h}$ at $4^{\circ} \mathrm{C}$. After precipitation with ammonium sulfate $(176 \mathrm{mg} / \mathrm{ml})$, the pepsin resistant proteins were resolved on 4-15\% SDS-PAGE without reduction and subjected to autoradiography. The intensities of the bands corresponding to $\alpha 1$ (III), $\alpha 1$ (I) and $\alpha 2$ (I) were quantitated with a scanning densitometer (Cliniscan Helena Laboratories).

\section{Collagen prolyl and lysyl hydroxylation levels}

Confluent cultures were labeled for $24 \mathrm{~h}$ with $\left[{ }^{3} \mathrm{H}\right]$ proline $(25 \mu \mathrm{Ci} / \mathrm{ml})$ and $\left[{ }^{14} \mathrm{C}\right]$ lysine $(1.25 \mu \mathrm{Ci} / \mathrm{ml})$ in lysine-free DMEM supplemented with dialyzed FBS $(0.5 \%)$ and ascorbic acid $(50 \mu \mathrm{g} / \mathrm{ml})$. The culture medium was precipitated with ammonium sulfate $(176 \mathrm{mg} / \mathrm{ml})$. The cell layer was homogenized with $0.5 \mathrm{M}$ acetic acid and centrifuged. The resulting supernatant was dialyzed against $0.1 \%$ acetic acid and lyophilized. The proteins in the culture medium and cell layer were combined and pepsinized as described above, then resolved on $4 \%$ SDS-PAGE under reducing condition. The bands corresponding to $\alpha 1(\mathrm{I}), \alpha 2(\mathrm{I})$ and $\alpha 1$ (III) were cut out and hydrolyzed with $6 \mathrm{M} \mathrm{HCl}$ for $18 \mathrm{~h}$ at $110^{\circ} \mathrm{C}$. The radioactive hydroxyproline, proline, hydroxylysine, and lysine were separated by HPLC (AA-pak $\mathrm{Na}^{+}$type, JASCO) and quantitated with a Beckman LS9800 liquid scintillation spectrometer. ${ }^{18}$

\section{Northern blot analysis}

Total RNA was isolated from cells. ${ }^{19}$ RNA samples were denatured in deionized $1 \mathrm{M}$ glyoxal $/ 10 \mathrm{mM}$ phosphate buffer, $\mathrm{pH} 6.5$ at $50^{\circ} \mathrm{C}$ for $1 \mathrm{~h}$, then resolved on $1 \%$ agarose gel electrophoresis $(10 \mu \mathrm{g} / \mathrm{lane})$ and blotted to nitrocellulose filters. The membranes were baked at $80^{\circ} \mathrm{C}$ for $2 \mathrm{~h}$ and hybridized to ${ }^{32} \mathrm{P}$-labeled probes in $50 \%$ formamide, $5 \times \mathrm{SCC}, 5 \times$ Denhardt's solution, $0.1 \%$ SDS, $250 \mu \mathrm{g} / \mathrm{ml}$ sonicated salmon sperm DNA at $42^{\circ} \mathrm{C}$ for $18 \mathrm{~h}$. The following cDNA probes radioactively labeled by random priming were used; pro $\alpha 1(\mathrm{I})$ collagen cDNA (Hf677), ${ }^{20}$ proo1(III) (Hf934) ${ }^{21}$ and ßactin cDNA (Oncor Inc) (specificativities $\sim 10^{8} \mathrm{cpm} / \mu \mathrm{g}$ DNA). The filters were washed at a stringency of $0.1 \times \mathrm{SSC}$ at $42^{\circ} \mathrm{C}$ for $1 \mathrm{~h}$ and exposed to $\mathrm{X}$-ray film at $-80^{\circ} \mathrm{C}$ with an intensifying screen. The autoradiograms were scanned with a densitometer.

\section{Determination of intracellular degradation of collagen}

The proportion of collagen synthesized by the fibroblasts that was degraded within the cells prior to secretion was determined as previously described. ${ }^{22.23}$ Briefly, cultures were shortly-pulsed with $\left[{ }^{3} \mathrm{H}\right]$ proline in the 
presence of ascorbic acid $(50 \mu / \mathrm{ml})$ for $30 \mathrm{~min}$ during the period the labeled collagen was still within the cells. The medium was aspirated and washed with PBS five times, then the cells were chased for $1 \mathrm{~h}$ in the medium containing unlabeled proline $(1 \mathrm{mM})$. The cell layers were scraped off from the plate using $10 \mathrm{ml} 0.5 \mathrm{M}$ acetic acid, then sonicated and heated at $100^{\circ} \mathrm{C}$ for $5 \mathrm{~min}$ to inactivate proteases. An aliquot was taken for quantitation of $\left[{ }^{3} \mathrm{H}\right]$ hydroxyproline using acid hydrolysis $(6 \mathrm{M} \mathrm{HCl}$, $\left.110^{\circ} \mathrm{C}, 18 \mathrm{~h}\right) .{ }^{18}$ Another aliquot was dialyzed against $1 \%$ acetic acid containing protease inhibitor cocktail at $4{ }^{\circ} \mathrm{C}$ for $48 \mathrm{~h}$, then the retentate was hydrolyzed for quantitation of $\left[{ }^{3} \mathrm{H}\right]$ hydroxyproline as described above. Percent dialysable ${ }^{3} \mathrm{H}$-hydroxyproline was calculated from the formula: $\%$ dialysable ${ }^{3} \mathrm{H}$-hydroxyproline $=$ (c.p.m. of total ${ }^{3} \mathrm{H}$-hydroxyproline in the sample) - (c.p.m. of ${ }^{3} \mathrm{H}$-hydroxyproline in the sample after dialysis) $\times 100$ / (c.p.m. of total ${ }^{3} \mathrm{H}$-hydroxyproline in the sample).

\section{Results}

The rate of collagen synthesis in the cell layer of the patient fibroblasts was greater than that in the control fibroblasts, whereas that in the medium counterpart was essentially the same (or unchanged) between the patient and control fibroblasts (Table 1).

There were no significant changes in the ratio of type III collagen to type I collagen, suggesting that syntheses of both type I and III collagens which were major collagens synthesized by skin bifroblasts were equally elevated (Table 2).

Table 1 Collagen Synthesis in the Medium and Cell Layer Fractions of Cultured Fibroblasts from Marfan Syndrome and Control Subjects

\begin{tabular}{lcc}
\hline \hline Cell Strain & $\begin{array}{c}\text { Relative Collagen Synthesis } \\
\text { collagen cpm }\end{array}$ \\
\hline & \multicolumn{2}{c}{ total protein cpm } \\
\hline medium & cell layer \\
\hline Patient & 0.40 & 0.07 \\
Control 1 & 0.37 & 0.08 \\
Control 2 & 0.38 & 0.03 \\
& 0.41 & 0.03 \\
& 0.41 & 0.02 \\
& 0.40 & 0.03
\end{tabular}

Cells were labeled with $\left[{ }^{3} \mathrm{H}\right]$ proline for $18 \mathrm{~h}$ in the presence of ascorbic acid $(50 \mu \mathrm{g} / \mathrm{ml})$. Collagen synthesis was determined with purificd bacterial collagenase digestion. Relative collagen synthesis was calculated by collagenase-sensitive counts/ total protein counts. Values indicate data obtained from duplicate experiments.
The levels of type I and III collagen mRNA were unaltered between the patient and controls (Fig 1), indicating that enhanced collagen synthesis is due to post translational events including prolyl and lysyl hydroxylation of collagen and intra- or extracellular degradation of collagen.

Prolyl and lysyl hydroxylation levels of type I and III collagens produced by patient fibroblasts were essentially

Table 2 Relative Synthesis of Type III Collagen in Marfan Syndrome Fibroblasts

\begin{tabular}{lc}
\hline \hline Cell Strain & Type III $\times 100 /$ type I + type III \\
\hline \multirow{2}{*}{ Patient } & 12.8 \\
& 14.1 \\
Control 1 & 15.1 \\
& 13.3 \\
Control 2 & 15.0 \\
& 13.6 \\
\hline
\end{tabular}

Cells were labeled with $\left[{ }^{3} \mathrm{H}\right]$ proline for $18 \mathrm{~h}$ in the presence of ascorbic acid $(50 \mu \mathrm{g} / \mathrm{ml})$. The proteins from medium and cell layer were combined and pepsinized for $18 \mathrm{~h}$ at $4^{\circ} \mathrm{C}(50 \mu \mathrm{g} / \mathrm{ml})$. Pepsin resistant proteins were resolved on SDSPAGE without reduction followed by autoradiography. Relative synthesis of type III collagen was expressed by type III collagen $\times 100$ /type I collagen + type Ill collagen from the autoradiograms. The values are from duplicate experiments.
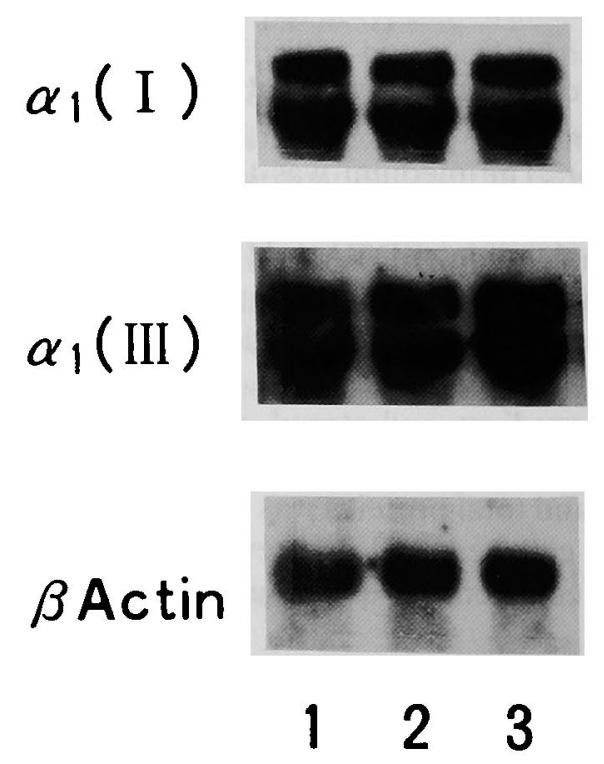

Fig 1 Levels of type I and III collagen mRNAs in the patient fibroblasts. RNA was extracted from patient (lane 1) and controls (lanes 2 and 3 ) fibroblasts, resolved by electrophoresis on $1 \%$ agarose gel and blotted to membranes. The filters were hybridized with a $1(1)$ or $\alpha 1$ (III) cDNA probes. 
Table 3 Prolyl and Lysyl Hydroxylation Levels of Collagens in Patient and Control Fibroblasts

\begin{tabular}{|c|c|c|c|c|c|c|}
\hline \multirow[t]{2}{*}{ Cell Strain } & \multicolumn{2}{|c|}{$\alpha 1(\mathrm{I})$} & \multicolumn{2}{|c|}{$\alpha 2(\mathrm{I})$} & \multicolumn{2}{|c|}{$\alpha 1($ III $)$} \\
\hline & Pro/Hyp & Hyl/Lys & Pro/Hyp & Hyl/Lys & pro/Hyp & Hyl/Lys \\
\hline Patient & 0.90 & 0.41 & 0.85 & 0.87 & 1.16 & 0.45 \\
\hline Control 1 & 0.97 & 0.42 & 0.81 & 0.88 & 1.16 & 0.48 \\
\hline Control 2 & 0.93 & 0.48 & 0.80 & 0.90 & 1.20 & 0.51 \\
\hline
\end{tabular}

Cells werc dual-labeled with $\left[{ }^{3} \mathrm{H}\right]$ proline and $\left[{ }^{14} \mathrm{C}\right]$ lysine in lysine-free DNEM for $18 \mathrm{~h}$. The proteins in the medium and cell layer were combined and pepsinized at $4^{\circ} \mathrm{C}$ for $18 \mathrm{~h}$. Pepsin resistant proteins were resolved on SDS-PAGE. The bands corresponding to $\alpha 1(\mathrm{I}), \alpha 2(\mathrm{I})$ and $\alpha 1$ (III) were cut out and hydrolyzed with $6 \mathrm{M} \mathrm{HCl}$ for $18 \mathrm{~h}$ at $110^{\circ} \mathrm{C}$. Labeled hydroxyproline, proline, hydroxylysine and lysine were separated on HPLC and counted with liquid scintillation counter.

Table 4 Intracellular Degradation of Collagen in Patient and Control Fibroblasts

\begin{tabular}{lc}
\hline \hline Cell Strain & \% Degradation \\
\hline Patient & 5.4 \\
Control 1 & 1.5 \\
& 23 \\
Control 2 & 27 \\
& 37 \\
& 29 \\
\hline
\end{tabular}

Cells were labeled with $\left[{ }^{3} \mathrm{H}\right]$ proline for $30 \mathrm{~min}$ and chased for $1 \mathrm{~h}$ The cell layer was disrupted with $0.5 \mathrm{M}$ acetic acid and dialyzed cxhaustively against $1 \%$ acctic acid. The samples prior or after dialysis were hydrolyzed in $6 \mathrm{M} \mathrm{HCl}$ for $20 \mathrm{~h}$ at $110^{\circ} \mathrm{C}$. ${ }^{3} \mathrm{H}$-Hydroxyproline was determined by HPLC column. Percent degradation was calculated as described in Materials and Methods. Values are from duplicate experiments.

unchanged compared to those in control fibroblasts (Table 3).

Intracellular degradation rate of collagen in the fibroblasts from Marfan syndrome was significantly lower than that in control cells (Table 4), indicating that the enhanced collagen synthesis may be caused by the reduced intracellular degradation rate of collagen.

\section{Discussion}

Intracellular degradation of collagen in control fibroblasts was $\sim 20-30 \%$, the values were in good agreement with the previously reported data. ${ }^{22,23}$ Intracellular protein degradation is believed to be controlled by the conformation of the proteins, but it is unclear what structural features in fact determine protein half-lives. ${ }^{15}$

Several abnormalities in collagen metabolism in Marfan syndrome have been previously reported. These include increased urinary excretion of hydroxyproline $e^{2,3}$ increased solubility of dermal collagen ${ }^{3,4}$ and decreased cross-links. ${ }^{5}$ In this study, reduced intracellular degradation of collagen was found in our case. These abnormal metabolism of collagen may be a secondary defect rather than a primary defect. Although the significance of the reduced intracellular degradation of collagen in Marfan syndrome is unclear at present time, this abnormality will result in the abnormal structural architecture of connective tissue because fine balance between synthesis and degradation is required for the physiological function of connective tissue.

\section{References}

1. Pyeritz RE: The Marfan syndrome. In: Royce PM, Steinmann B, eds, Connective Tissue and Its Heritable Disorders, New York, Wiley-Liss, 1993, 437-468

2. Prockop DJ: The intracellular biosynthesis of collagen; some possible implications for diseases of bone and other connective tissues. Arch Intern Med 1969, 124: 563-570

3. Laitinen $\mathrm{O}$, Uitto J, Iivanainen $\mathrm{M}$, Hannuksela $\mathrm{M}$, Kivirikko KI: Collagen metabolism of the skin in Marfan's syndrome. Clin Chim Acta 1968, 21: 321-326

4. Priest RE, Moinuddin JF, Priest JH: Collagen of Marfan syndrome is abnormally solublc. Nature 1973, 245: 264-266

5. Boucck RJ, Noble NL, Gunja-Smith Z, Butler WT: The Marfan syndrome: a deficiency in chemically stablc collagen cross-links. N Engl J Med 1981, 305: 988-991

6. Appcl A, Horwitz AL, Dorfman A: Cell-free synthesis of hyaluronic acid in Marfan syndrome. J Biol Chem 1979, 254: 1219912203

7. Lamberg SI: Stimulatory effect of exogenous hyaluronic acid distinguishes cultured fibroblasts of Marfan's disease from controls. J Invest Dermatol 1978, 71: 391-395

8. Pulkkinen L, Kainulainen K. Krusius T, Mäkinen P, Schollin J, Gustavsson KH, Peltonen L: Deficient expression of the gene coding for decorin in a lethal form of Marfan syndrome. J Biol Chem 1990, 265: 17780-17785

9. Gunja-Smith Z, Boucek RJ: Desmosines in human urinc: amounts 
in early development and in Marfan's syndrome. Biochem J 1981, 193: 915-918

10. Abraham PA, Perejda AJ, Carnes WH, Uitto J: Marfan syndrome. Demonstration of abnormal elastin in aorta. J Clin Invest 1982. 70: $1245-1252$

11. Lee B, Godfrey M. Vitale E, Hori H, Mattei MG, Sarfarazi M, Tsipouras P, Ramirez F, Hollister DW: Linkage of Marfan syndrome and a phenotypically related disorder to two different fibrillin genes. Nature 1991, 352: 330-334

12. Maslen CL, Corson GM, Maddox BK, Glanville RW, Sakai LY: Partial sequence of a candidate gene for the Marfan syndrome. Nature 1991, 352: 334-337

13. Dietz HC, Cutting GR, Pyeritz RE, Maslen CL, Sakai LY, Corson GM, Puffenberger EG, Hamosh A, Nanthakumar EJ, Curristin SM, Stetten G, Francomano CA: Marfan syndrome caused by a recurrent de novo missense mutation in the fibrillin gene. Nature 1991, 352: 337-339

14. Pyeritz RE, Francke U: Conference report: the second international symposium on the Marfan syndrome. Am J Med Genet 1993, 47: 127-135

15. Goldberg AL, St John AC: Intracellular protein degradation in mammalian and bacterial cells: Part 2. Annu Rev Biochem 1976. 45: 747-803

16. Peterkofsky B, Diegelmann R: Use of a mixturc of proteinasefree collagenases for the specific assay of radioactive collagen in the presence of other proteins. Biochemistry 1971, 10: 988-994
17. Phillips CL, Tajima S, Pinnell SR: Ascorbic acid and transforming growth factor- $\beta_{1}$ increase collagen biosynthesis via different mechanisms: coordinate regulation of pro $\alpha 1(\mathrm{I})$ and pro $\alpha 1(\mathrm{III})$ collagens. Arch Biochem Biophys 1992, 295: 397-403

18. Tajima S, Murad S, Pinnell SR: A comparison of lysyl hydroxylation in various types of collagen from type VI Ehlers-Danlos syndrome fibroblasts. Coll Relat Res 1983, 3: 511-515

19. Chomczynski P, Sacchi N: Single-step method of RNA isolation by acid guanidinium thiocyanate-phenol-chloroform extraction. Anal Biochem 1987, 162: 156-159

20. Bernard MP, Chu ML, Myers JC, Ramirez F, Eikenberry EF, Prockop DJ: Nucleotide sequences of complementary deoxyribonucleic acids for the pro 1 chain of human type I procollagen. Statistical evaluation of structures that are conserved during evolution. Biochemistry 1983, 22: 5213-5223

21. Chu ML, Weil D, de Wet W, Bernard M, Sippola M, Ramirez F: Isolation of cDNA and genomic clones encoding human pro$\alpha 1$ (III) collagen. Partial characterization of the 3 ' end region of the gene. J Biol Chem 1985, 260: 4357-4363

22. Bienkowski RS, Baum BJ, Crystal RG: Fibroblasts degrade newly synthesized collagen within the cell before secretion. Nature 1978, 276: 413-416

23. Baum BJ, Moss J, Breul SD, Berg RA, Crystal RG: Effect of cyclic AMP on the intracellular degradation of newly synthesized collagen. J Biol Chem 1980, 255: 2843-2847 